\title{
Michael Olejniczak
}

\section{Long-term Unemployment and the Capability Approach - The Case of the German Labor Market}

This text focuses on long-term unemployment in the German labor market caused by insufficient work skills capabilities and discusses the deficits of the current policy in improving the situation of job seekers who are repeatedly rejected in their efforts to find a job. For both the German approach to this problem as well as for the European labor policy a neoliberal orientation is still the paradigm, complemented in part by social democratic ideas and labeled "New Deal". Distinct to the incoherent normative foundations of labor policy, the EU favors the normative base of the capability approach for measuring wealth and poverty. The capability approach (CA) provides a comprehensive, normative instrument for evaluation of individual welfare and social structures as well as a certain orientation of social policy. The text discusses the deficits of the current labor market policy and suggests the capability approach as a perspective for a new policy.

Key words: long-term unemployment, capability approach, employability, labor policy (JEL: D60, E24, E61, H11, H50: I38, J08, J14, J20, J64, J68)

\footnotetext{
* Michael Olejniczak, Werkstatt für Organisations- und Personalforschung Berlin e.V., Buschweg 3, 32339 Espelkamp, Germany. E-mail: bzldozent@yahoo.de.

** Article received: June 7, 2011

Revised version accepted after double blind review: February 24, 2012.
}

management revue, 23(2), 140-157

ISSN (print) 0935-9915, ISSN (internet) 1861-9908
DOI 10.1688/1861-9908_mrev_2012_02_Olejniczak

(C) Rainer Hampp Verlag, www.Hampp-Verlag.de 


\section{Introduction}

Since the 1990s the German labor market has been characterized by a high level of long-term unemployment. This has overstrained the design of the traditional welfare state. At the same time the EU has tried to integrate the social democratic ideas of the resources-based view of employment policy and neo-liberal orientation to market opportunities with the purpose of reclaiming human resources for the economy (Bonvin, 2007a). The political reform discussion was based on the concept of the poverty trap (Gebauer et al. 2003), principles of a new public management aiming at activation and strengthening of agencies. Having dropped the former objective of "full" employment, the new operational target dimensions were not sufficiently defined and clearcut (Deakin, 2005), and their instrumental details were checked without applying the basic definition of empowerment. This has led to unsatisfactory evaluation of the employability and the quality of service processes.

According to A.K. Sen the shortfalls in a consistent normative concept for policy and evaluation could be recovered through the CA. This viewpoint is vetted here as a theoretical background and a normative basis of labor policy for long-term unemployment in Germany. The contractualization of social services on the individual level instead of general standardized services for all is the gist of these reforms and the CA seems to provide largely congruent by empowering agency and strengthening personal capabilities. (Bonvin, 2009)

The older post-war welfare states targeted the dimension of resources in order to guarantee a minimum of subsistence for everyone. The new public management concepts, based on market liberalism, are trying to force a certain result for everyone, in this case the state of being employed. The CA demands more freedom for the individual; it postulates that empowered capabilities of being hired in a job are considered to be "valuable" - the major freedom in this context - and promotes "autonomous" people, and not employment as the obligatory functioning for everyone (Bonvin, 2009). Employment policy based on the CA asks for a minimum of capabilities for everyone. Society as a whole will profit from increasing instrumental freedoms and capabilities of citizens (Volkert, 2005b).

In industrial economies well-being is strongly dependent on jobs. The consequences of unemployment go beyond a simple lack of income; it severely limits future opportunities. Even though in most European countries material poverty is not the result of unemployment (this risk is transferred to the state budget) the list of its individual after-effects is long, and discrimination can be enforced (Sen, 1999). The longer unemployment lasts, the more skills and competences are lost - rapid technological change renders qualifications worthless.

The following text first describes the situation on the German labor market and labor market policy, characterized by a series of reforms. After a short description of the CA, the basics of the approach will be applied to the field of labor. Next the discrepancies concerning the normative standards of the CA will be explored and, finally, the basic requirement for the implementation of a CA-oriented labor policy will be examined. 


\section{The current labor market policy in Germany}

\subsection{Characteristics of long-term unemployment in Germany}

The German labor market is clearly divided: on the one hand, plenty of permanent job offers for skilled candidates, on the other hand, strict flexibility is expected of lessskilled employees. The German social security system is split into the insurance-based unemployment benefit I system (UB I) for the short-term unemployed and tax-based unemployment benefit II (UB II) for other job seekers. The development into these two systems over the period from 2005 to 2010 exposed serious problems in longterm unemployment. While the number of UB I unemployed declined from $1.43 \mathrm{~m}$. to $0.88 \mathrm{~m}$., the number of unemployed UB II recipients only decreased from $2.73 \mathrm{~m}$. to $2.07 \mathrm{~m}$. About 4.9 million people in Germany including family members and children are dependent on UB II (Bundesagentur, 2011a).

Although the unemployment rate approximately doubled from 1975 to 2009, the unemployment rate among people without occupational training has more than tripled (IAB 2011). Structured data reveal certain groups with the highest risk of exclusion from the labor market - almost importantly people without any or with only low occupational qualifications.

Job opportunities for people with severe health problems are as bad as for the low-skilled. There is evidence of physical or psychological restrictions for $35 \%$ of the UB II recipients. Almost no research results about the impact of personality disorders on unemployment are available yet; for the German population the prevalence of personality disorders is likely to be around $10 \%$ to $12 \%$ (Berger, 2009). Personality disorders are viewed as inability to adequately adjust social behavior which leads to sanctions and dismissal (DGPPN, 2009). According to medical experts personality disorders are not an indication for inability to work as long as they do not reach the level of a psychiatric disease (Stadtland \& Nedopil, 2008).

Single parents are also suffering from unemployment more than the average: 41 $\%$ of all single parents depend on UB II, and the entitlement is longer than on average (Lietzmann, 2009). Unemployment statistics among the UB II job seekers also show a disproportionately high unemployment rate for immigrants $(24.8 \%)$, and job seekers above 50 (24.1\%) (Bundesagentur, 2011).

The rate of fixed-term job contracts is steadily growing, even for highly-skilled workers. It reached its peak at $9.3 \%$ before the economic crisis in 2008 , whereas the ratio of $8.8 \%$ in 2009 was caused by the expiration of contracts (Hohendanner, 2010). Temporary work increased from $1.1 \%$ in 2003 to $2.6 \%$ in 2008 and then dropped to $1.9 \%$ in summer 2009 at the peak of the crisis. With the economy recovering, temporary work is quickly growing again (Bundesagentur, 2010). For temporary employees the risk of losing their jobs is very high while their wages are low.

\subsection{Recent reforms of the labor market}

For more than a decade labor policy has been subject to several reforms predominantly fostering liberalization of labor by temporary work and fixed-term employment contracts. Efforts were also made to cut back on bureaucracy and create a modern service agency, controlled by a new governance concept to promote customer- 
orientation, effectiveness, efficiency and employee satisfaction (Schütz, 2008). A complex monitoring system and standardized processes for efficiency were implemented (Schütz, 2008).

The policy of the late 90 s was oriented toward cutting expenses in the former unemployment benefit system while the number of long-term unemployed was growing steadily. The federal government passed the costs for labor market mismatch on to the municipal administrations who were unprepared for the expense (Kaps, 2006). In this controversial discussion the government implied that recipients were rationally maximizing their utility by staying unemployed although available studies revealed that their motives were more complex than this simple poverty trap (Gebauer et al., 2003). In fact, alongside egoistic-material motivation emotional incitements are also evident in endeavors to find a job (Sesselmeier \& Yollu-Tok, 2007).

The most spectacular reforms were the so-called "Hartz Reforms", put forward by the Hartz Commission in 2002 and based on suggestions for reducing unemployment and restructuring the federal employment agency. Besides renewing the clamor for new organizational structures and customer orientation, the commission report proposed one integrated service system managing all unemployed to avoid the negative consequences of cream skimming between parallel systems. Case management as a new service for low potential customers to enforce their employability was suggested (Kommission 2002). The goal of creating one integrated system to manage unemployment was abandoned and the focus is still set to job placement rather than to case management.

Above all, the German reform follows the international trend of neo-liberal reorganization of the welfare state with such features as activating productive potentials of recipients, adjusting agency to the local or regional level and reciprocity of benefits and efforts, expressed in integration contracts ( $\mathbb{1} 15$ SGB II). The old concept of the welfare state, granting payments to compensate social risks, appears to have been superseded (Bonvin, 2007a). The government has failed to offer arguments for legitimization of this change to a system with intense pressure for activation and strict regulations on what constitutes a reasonable job offer ( $\mathbb{S} 10$ SGB) and caused a unique polarization in society (Konle-Seidl, 2008).

\subsection{Governance and the new public management}

The change of labor policy in Germany has been accompanied by a change of governance in this field. As the administrative implementation of political reforms strongly influences the relationship between people and government, it is remarkable that the change of governance was not intensively discussed in public (Konle-Seidl, 2008).

For short-term unemployed the service is still offered by the federal employment agency as a para-fiscal institution. Politics took effect by staffing the board of directors while in the reforming process the influence of trade unions and employers' associations was drastically reduced. The federal employment agency is independent in operative decisions, and the services framework is politically set by the Social Act III. The reform intended to increase effectiveness and efficiency by changing the control structure from management by directives towards a system of management by objectives. The strict hierarchy of the old administration was supposed to be abolished and job 
centers were to be local actors, have more autonomy (Konle-Seidl, 2008). The counselors, job coaches and case managers were to be freed from administrative and minor tasks in favor of improved service to the customers (Kommission, 2002).

The service for long-term unemployed subject to the Social Act II was assigned to job centers on a local scale and organized as cooperation of the federal employment agency with municipal administrations. The tax-funded allowance for subsistence is directed by the municipal administrations while active services for integration into work are guided by the federal employment agency. External services were envisaged to be acquired by quasi-market instruments; training and placement vouchers were introduced to give customers the agency of choice, and tender procedures are obligatory for buying complete seminars or projects. Audits certify quality of the measures to ensure a minimum level of quality (Konle-Seidl, 2008). In order to configure their services flexibly according to $\int 16$ SGB II the agency for local job centers had to undergo dramatic changes. First legal reforms in 2009 deprived this agency to a certain degree, but another pending reform of instruments is designed to grant more flexibility again in 2012 (BMAS, 2011).

All employees who lose their job after being employed for at least 12 months can claim insurance-based allowance UB I by the federal employment agency. Budgets are split up in accordance with the chances of placement. Although the case management for the weaker customers is extremely complicated, costly and time-consuming, only a small part of the budget is allocated to this group. Within the circular process of case management, placement obstacles are to be eliminated and agency of these unprivileged customers is to be promoted (Arbeitskreis, 2004).

When entitlement to UB I ends or the allowance is not sufficient, customers can claim the tax-based UB II. Most of the active instruments offered by the Social Act III are also available in the UB II-system ( $\$ 16$ SGB II). In addition to this, $₫ 16$ a Social Act II obliges the municipal governments to provide support for child care, debt counseling, psychosocial consultancy and addiction counseling. Furthermore, work opportunities for a stabilized life should be created for customers through case management ( $\int 16 \mathrm{~d}$ SGB II). Customers in the UB II system are categorized as well, and here also the emphasis is on job placement of customers with good placement prognosis rather than on intense case management and strengthening capabilities for customers who lack resources.

\subsection{Problems of the current labor market policy}

Belonging to the middle class no longer confers social security. As almost any kind of job regardless of qualification level or payment is considered be reasonable for the long-term unemployed, it has not only an impact on the unemployed but also on employees who fear losing their jobs. Counseling partly takes the shape of social control and individual actions are aimed more at checking attitudes of job seekers than at targeting job placement or empowerment. Although many customers are victims of market processes and there are no suitable jobs for them, they are blamed for being unemployed (Behrend et al., 2007). The announced principle of strengthening agency had to take a back seat to the goal of activation, and employment becomes an obligatory functioning, cutting back the freedom of choice (Bonvin, 2009). 
The allocation of resources for services explicitly favors the group of unemployed with good placement chances. Customers with unfavorable placement prospects after the 12-month UB I entitlement drop off into the UB II system without any placement activity (Hielscher \& Ochs, 2009). For the sake of efficiency, cream skimming between concurrent security systems - indicated as a malfunction by the Hartz Commission - is still functioning as a component of the current system. Generic profiling is not suitable for analyzing customers' resources with respect to individual strategies in job placement or to actions of empowerment (Ames, 2008b). Customers' interests in individual services are secondary to constraints resulting from controlling and target agreements for job centers and counselors (Hielscher \& Ochs, 2009). Individual advisers must meet not only their own individual target agreements but also the standards on the job center level (Behn, 1994), and even without external pressure, the professional will resort to cream skimming to achieve positive results (Lipsky, 2005).

The employment rate has increased, but at the same time the phenomenon of the working poor has become far more widespread: in January 2005, 0.76 million people needed UB II alongside wages; this number rose to 1.24 million in October 2007 (Bundesagentur, 2011a). Employers take advantage of this indirect wage subsidy (Eichhorst \& Zimmermann, 2007) and the incentive to do so is provided by the lack of a legal minimum wage. The temporary approach enlarges the number of jobs by pushing wages down below a sensible level, ignores qualitative aspects of work and adjusts the production factor "labor" to the market, but does not supply the unemployed with adequate jobs (Bonvin, 2007a).

For people with lower qualifications the choice lies mostly between a low-paid job without any intrinsic motivating element, on one hand, and more or less satisfying social entitlements - possibly even exceeding the earnings in a hard, dirty and not really satisfying job - on the other hand. If customers reject a job, this is seen as welfare fraud and abuse of social benefits, not taking into account working conditions, insufficient wages and individual factors (Ames, 2008a; Bescherer et al., 2008; \10 SGB II). Such conflicts are not adequately discussed in politics and a satisfying co-production in the service process between advisers and customers is complicated by this fact. The new concept offers no security for people pushed into joining the rank of working poor: after losing these jobs they again return to the UB II subsistence allowance (Seifert, 2007; Bartelheimer, 2010). The impression of "being a victim" of a suppressive system is widespread among clients: $34.2 \%$ of visitors report a friendly atmosphere in the interviews, but nevertheless feel like they are being treated in a condescending manner, and $35.7 \%$ feel rejected when they ask for support (Ames, 2008b).

Another impediment to sustainable success is the discontinuation of consulting services and other assistance as soon as the achieved income surpasses the UB II entitlement. Many customers with serious placement hindrances are overcharged with this activation-oriented process (Ames, 2009) which forces a great number of applications, ignoring the customer's individual factors and the situation on the labor market. These forced efforts cause numerous failure experiences for the unemployed, who always end up getting "what's left over" in the cream skimming process of selection. The result of this process is self-underestimation which causes further failures, which in turn confirm the negative self-image. Pressure turns into psychic violence - not caused by 
consultants who have lost their humanity, but rather the post-solidary spirit of reciprocity of social benefits (Behrend, 2008). Self-esteem and self-confidence decline and in the worst case severe depressions are the result (Halapier et al., 1996).

Surveys also show a lack of customer orientation: more than $40 \%$ of clients perceive job centers as only claiming actions, but do not really see them as providing support. More than $50 \%$ do not even feel that they are being helped to find a job (Tisch, 2010). Up to $75 \%$ of requests for occupational qualification to obtain skills certificates were rejected. Only $18.6 \%$ of participants feel some improvement due to measures undertaken while $43.6 \%$ see no use for integration into the labor market (Ames, 2008b). This low acceptance of qualification measures can be traced back to the fact that many activating measures are labeled as qualification measures. Statisticoriented placement of the unemployed into activation measures and work opportunities without considering the individual needs are perceived as arbitrariness by the clientele (Olejniczak, 2010).

Job center professionals complain of poor supply of suitable measures, decreasing time-allocation for interviews owing to increasing requirements in administrative and statistical tasks, and of the managerial neglect of qualitative aspects, focusing on fulfilling requirements of statistics (Ames, 2008a). They are excluded both from the design of the system and from evaluation. The evaluation and controlling system is designed to provide politicians with "success" indicators (Bouché, 2008). The orientation towards data on the macro-level overshadows the impact on the individual level (Ames, 2008a). This is demotivating for job center professionals with a pedagogical background or work experience in private business (Hielscher \& Ochs, 2009) and explains the high rate of fluctuation in job centers (BMAS, 2008). Through the implementation of the new public management with its strict rules and domination of controlling and benchmarking of standardized figures, hardly any local agency is left. Targets are given top down; instructions elicit resistance on the operational level. As conflicts are not resolved within this rigid system, pro-forma commitment and manipulation of indicators on the operational level are the predictable output. Transfer of fullypledged agency over to the local level, as it is stipulated in the European guidelines, does not seem to be prevalent in Germany after years of reforms in labor market administration (Bonvin, 2007a).

Figure 1: Characteristic features of current policy on long-term unemployment

\begin{tabular}{|l|}
\hline \multicolumn{1}{|c|}{ Targets } \\
\hline Functionings: \\
- Employment \\
- Activation \\
- Agency \\
Recovery of \\
human resouces \\
Reciprocity \\
\hline
\end{tabular}

\begin{tabular}{|l|}
\hline \multicolumn{1}{|c|}{ Governance } \\
\hline $\begin{array}{l}\text { Controlling and } \\
\text { budgeting } \\
\text { Categroized } \\
\text { customers and } \\
\text { standardized } \\
\text { instruments } \\
\text { Priority of job } \\
\text { placement }\end{array}$ \\
\hline
\end{tabular}

\begin{tabular}{|l|}
\hline \multicolumn{1}{|c|}{ Evaluation } \\
\hline "Short termed" \\
$\begin{array}{l}\text { Orientation on } \\
\text { market and } \\
\text { resources } \\
\text { Quantitative view }\end{array}$ \\
\hline
\end{tabular}

\begin{tabular}{|c|}
\hline Results \\
\hline $\begin{array}{l}\text { Subsidizing low } \\
\text { productive jobs }\end{array}$ \\
\hline $\begin{array}{l}\text { Growing number } \\
\text { of working poor }\end{array}$ \\
\hline $\begin{array}{l}\text { Cream skimming } \\
\text { and discriminatio }\end{array}$ \\
\hline $\begin{array}{l}\text { Constraints and } \\
\text { lack of freedoms }\end{array}$ \\
\hline
\end{tabular}




\section{Capabilities and work}

\subsection{The capability approach}

Before applying the CA to the phenomenon of long-term unemployment, a short overview of the approach with its basic elements and normative principles needs to be outlined. Sen's approach is based on normative theoretical reflections on poverty, justice and freedom. The further concept of the CA stems from the presumption that freedom to live a life considered to be valuable is more relevant for judging wealth or poverty than looking at measurable material property. Therefore the CA does not focus on material resources obtained by an individual, but on the functionings (as valuable beings and doings) it aspires to and is able to realize through free choice (Sen, 1999). Sen's CA is more comprehensive than a resource-based view of welfare; the CA shifts attention to inequity as of lack of freedoms (Sen, 1999). The focus is on capabilities for individual self-realization, whereas lack of material resources can be both the reason for deficiency in capabilities and also the result. Capabilities and restrictions are determined by a wide range of influences apart from income.

To actualize functionings as the conditions of real life, the individual needs -- beyond material resources -- a set of conversion factors in order to be able to utilize those resources. The traits of life as a result of obtained resources, conversion factors and individual decisions are seen as achieved functionings (Bonvin, 2009). The CA does not set the scope to the achieved functionings but refers to the set of possible functionings a human being can achieve (Arndt \& Volkert, 2007). The relationship between low income and low capabilities is variable within different cultures, families and individuals. In this concept the welfare of a person is not only dependent on individual resources but also on the capability set and the freedoms of an individual.

Capabilities are the set of possible functionings determined by resources and conversion factors and the individual's freedom of choice to select the desired functionings for the actualized life (Sen, 1999). It is obvious that capabilities are not only determined by restrictions but are also determined by a variety of options and the selective criteria according to individual preferences (Volkert, 2005a). They depend on the setting of personal conversion factors that can be distinguished in individual, environmental and social matters influencing the transformation of resources into achieved functionings (Kuklys, 2005; Robeyns, 2005). For example, a car as a resource will not increase capabilities if no streets are available - a bicycle for a woman will not strengthen capabilities in societies which do not accept women riding a bicycle.

Individual conversion factors can be understood as restrictions directly related to individual skills or physical abilities, work life experiences, psychic disposition, age and gender, and directly influencing employment possibilities (Drilling, 2004).

Environmental conversion factors refer first and foremost to the infrastructure of the immediate environment of the individual. Of particular importance here are traffic facilities as well as educational infrastructure and economic structure, also regional habits, norms and values.

Social conversion factors are set by governmental policy, jurisdiction, general code of conduct and public administration. Also the position of the individual within a hierar- 
chical order of a society influences the opportunities for participation (Robeyns, 2005).

Conversion factors are crucial for actualizing capabilities, especially for the labor market (Deakin, 2005). In work life, occupational skills related to production technology are most important (Goerne, 2010). In this way, insufficient capabilities of disabled individuals can be interpreted as kind of a weak set of conversion factor combined with extra needs (Kuklys, 2005).

The actual life situation depends not only on capabilities, but also on individual decisions (Drilling, M. 2004) and instrumental freedoms as opportunities determined by the community. In this context transparency and access to information are the prerequisite for all the other instrumental freedoms, as there are social and economic opportunities, social security, ecological security, political opportunities and transparency (Volkert, 2005b)

Instrumental freedoms include the process aspects, processual freedom and opportunity freedom. Processual freedom means the opportunity to participate in the process of designing and implementing policy that has an impact on living conditions.

Opportunity freedom means the freedom of choice between different options - a basic requirement to obtain individual welfare by the means of capabilities (Sen, 1999). Here more than just the option to exit should be given: the chance to voice, to criticize and influence regulations, but also the option to be loyal to common norms and values (Seifert, 2007). Within the CA, agency is related more to freedom of choice than to the ability to achieve an external imposed target (Sen, 1999).

Figure 2: The personal capability set in the context of personal properties (according to Robeyns, 2005)

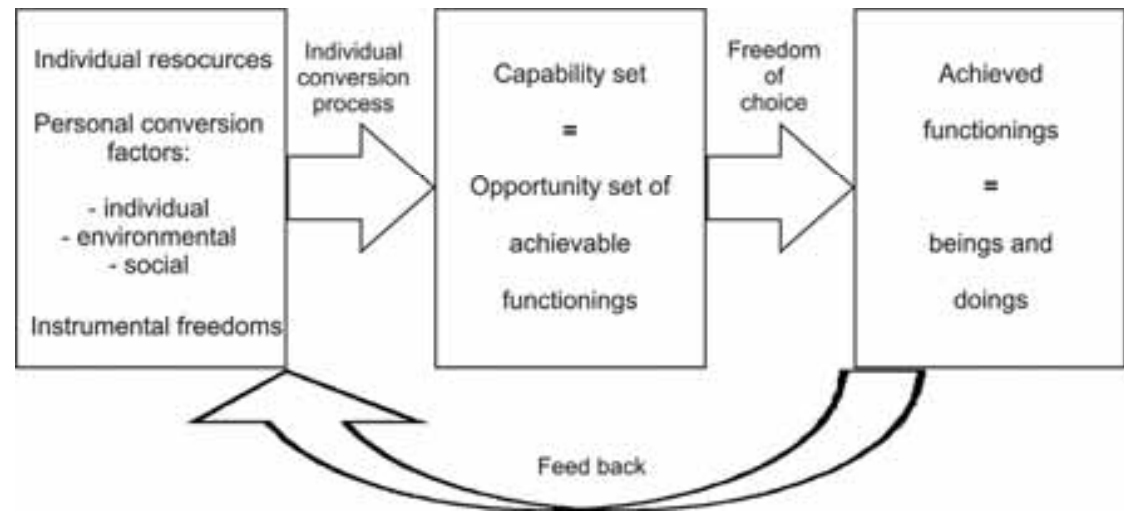

\subsection{Long-term unemployment as a result of insufficient capabilities}

Unemployment is considered to be a mismatch on the labor market. In terms of the CA the focus of vision shifts from the macro-view of the market over to causes and effects of unemployment on the individual level. In Europe income and prestige received as a result of work serve, apart from family and social origin, more and more as a foundation for accumulating social and cultural capital (Drilling, 2004). Unemploy- 
ment limits capability by limiting resources, restricts conversion factors and reduces instrumental freedoms as structural phenomena (Drilling, 2004) with the risk of being inherited by future generations. Social and even family relationships become dispersed or disrupted; governmental regulations limit the freedom of individual choice (Volkert, 2005b).

For the unsuccessful candidate, rejections of job applications result in the impression of being rejected by society and evoke a feeling of discrimination (Vogel, B. 1999). This generates a sort of vicious circle, as social networks always play an important role in seeking a job (Granovetter, 1995). The destructive effect of unemployment on mental health is fatal and continues to grow with lasting unemployment. Psychiatric diseases and addiction risks ensue (Berth et al., 2008).

Such factors as motivation, cognitive skills, social networks (Apel \& Fertig, 2008), physical and mental health can be said to fit well with the theoretical concept of conversion factors within the capability approach. These are placement obstacles that can be considered to be lacking conversion factors as well as restrictions of employability. Employability is currently the major issue of active labor policy alongside job placement (Bonvin, 2007a).

Employability means the aptitude to apply functional, social and methodical competences and further skills in the face of restricting environmental factors (Kraus, K. 2008), including personal resources such as qualification, employment experiences, intellectual skills, health, personality and social factors (Apel \& Fertig, 2008). Employability is given to all individuals, but its level varies, and a certain threshold must be exceeded to be competitive on the labor market (Pfeifer et al., 2008). Education as a component of employability is more than just an individual conversion factor. It is also valuable as intrinsic and social means and promotes individual self-actualization and self-determination (Dietz et al., 2009). The same holds true when the achieved position in working life provides resources, affects the personal conversion factors and achieved functioning (respect of others, chances for participation in public life and education, self-esteem and social security). This feedback-effect can cause a counter-cycle with destructive effects in the course of a period of unemployment.

The first step toward acquiring employability is primary education (Walker, 2010). As the OECD studies show, the educational system in Germany fails to eliminate social exclusion. Children from families with a lower educational level have poorer expectations for higher education (Valtin, 2008) because opportunities in working life with professional success and income depend heavily on the social status of the parents (Pollak, 2006; Andersen et al., 2007). A large number of young, less-successful school-leavers have problems finding vocational training after school. School does not sufficiently prepare pupils for life with regard to functional knowledge and social skills (Seibert \& Kleinert, 2009). Combined with other personal disadvantages, the situation can grow desolate as, for example, a survey of undereducated young female immigrants shows (Damelang \& Haas, 2006). The core of this problem is unsuccessful integration policy and education system - therefore sustainable solutions are rarely to be found in the sphere of labor policy. 
As employers expect a lower level of physical and intellectual performance by older workers, age also becomes a limiting factor of employability and such employees are often disconnected from continuous training programs.

Poor employability can also stem from limited environmental conversion factors. First of all, the lack of childcare facilities to match the common business hours is a big obstacle, especially for single parents (Drilling, 2004). A similar problem is geriatric home care or home care for disabled people in the family: the social security system prefers family members as caretakers. In a traditional society women fall victim to this type of exclusion. Regional aspects also influence employment as there are few jobs in economically depressed areas. The provision of public transportation facilities also improves employment opportunities for people without a driving license or a car. Even training measures are often unattainable for people from the suburbs or the country (Olejniczak, 2010).

Social conversion factors in the sense of the CA refer to social and cultural capital (Bourdieu, 1983). In many cases long-term unemployment causes a withdrawal from social contacts and society, so social capital is lost. Personal networks dissolve and most of the remaining contacts are people in the same situation, although the importance of personal networks for finding jobs is well known (Granovetter, 1995).

Personal capabilities depend on freedoms. In this context freedom means first of all the freedom of choice between alternatives. There must be a reasonable supply of alternative job offers to choose valuable work (Bonvin, 2007a). The matters of employability, valuable work and the right to free choice including the right to refuse a job and to resign from an under-valued or unsuitable job without financial sanctions are interdependent (Salais, 2004; Bonvin, 2007a). Freedom of choice leads to problems if the unemployed have no inherent desire to work. There is no evidence as to whether humans in general have a need to work (Wacker, 2001). Empirical research on this issue is tricky - obviously some people do not take on jobs offered, but information on reasons is not available.

The freedom to participate in designing employment policy and regulations for reasonable work are also crucial elements of the CA. For the CA the definition of valuable work is not an individual but a collective decision. If the decision of whether the job in question is valuable is made by the collective, the people concerned should at least have a chance to influence the process of creating rules (Bonvin, 2007a).

\section{Aspects of the implementation of a CA-oriented labor policy}

The CA is discussed mostly in the wider framework of social policy, evaluating wealth and poverty by the means of justice (BMAS, 2005). Applying this approach as a normative foundation to labor policy, the interdependency with social and economic policy becomes clearly visible. The lack of compliance with one common normative orientation of both these areas of policy might be the reason for a lacking conceptual undermining of labor policy. In order to apply a CA-oriented labor policy, politics in general must accept the overriding normative goal of individual freedoms as a prerequisite for social justice.

The CA is related to a multi-faceted and complex reality and concerns different areas of politics such as health care, education, labor code. Labor policy can be con- 
sidered the core of a general concept in CA-based policy (Arndt \& Volkert, 2006) if it is synchronized with other fields of politics to make it effective. Freedom of individual choice, personal conversion factors and employment as operational target dimensions for a CA-oriented labor policy are truly interdependent (Arndt \& Volkert, 2006). Much effort must be invested in an integrated system of social security and empowerment to overcome the limited view of employability and to enhance the capabilities of whole families (Nicaise, 2007).

The priority for labor policy within the framework of the CA is to make it possible for everyone to have the opportunity for valuable or merit-based work (Bonvin \& Farvaque, 2005). As policy is a result of compromises within the political process, an implementation of a CA-oriented labor policy cannot be expected to be fully congruent with a set of logical deductions from the normative paradigm, but should at least try to come close.

\subsection{Counseling requirements and CA-compatible measures}

Swedish social policy strictly oriented towards participation of all people in working life, is successful and quite compatible with endeavors using the CA-approach. (Nicaise, 2007). In most of Scandinavia generous social benefits are based on the priority of equal opportunities, trust and participation in labor life. Provisions for childcare and early-childhood education not only enable single parents to work, but they also improve their social mobility and strengthen employment capability at a very early stage (Andersen et al., 2007). Adequate support of special groups, particularly longterm unemployed, has shown notable success in Sweden (Zierahn, 2008), which is quite distinct to the German practice of employing cream skimming as an instrument.

For the consultation process it is necessary to apply the method of case management consistently: a customer-oriented service as an interactive co-production between customer and consultant, perceived as trustful and requiring support suitable to the customer's individual needs. The current system rests on the key assumption that customers are not willing to work, which is counterproductive to the requisite trustful relationship. Profiling of the long-term unemployed should be intensified and result in individual training programs and in-depth advising which could help overcome placement obstacles like addiction, psychiatric problems, over-indebtedness, lack of mobility and others. As many problems are not solved at the time of gaining employment and losing UB II entitlement, further coaching to increase sustainability of effects should be possible.

The necessary measures should cover a variety of alternatives meant to match the whole range of customers' problems and needs (Goerne, 2010). Obviously activation measures should be restricted in case of self-induced shiftlessness (Forgas \& Frey, 1999), personal or behavioral disorders and there should be sophisticated projects with collaboration from psychologists and social workers. Activation projects applying pressure are less expensive in the short term, but in the long run sustainable effects are not satisfying. Furthermore, the limited view on the budget of the labor administration ignores material synergy effects on other fields of policy and non-monetary after-effect of freedom and improved capabilities. Emphasis should be made on adequate qualification measures meeting the requirements of the labor market. An analog 
pattern to a concept of valuable work, measures and employment opportunities for jobless should be configured in a way that they can be considered valuable by the participants.

The core problem of long-term unemployment is the lack of valuable jobs the unemployed have sufficient potential to fulfill the job requirements and at the same time offering conditions that are attractive enough to apply for by free choice - valuable jobs provide acceptable working conditions and wages more attractive than the receipt of social benefits. In order to have a chance for such a position, job training is often needed (Bonvin, 2007a). For the unemployed with insufficient capabilities, suitable jobs must be created by the public administration. Current policy is already oriented towards fostering employment of disabled people through regulations and subsidies to compensate for what they lack in productivity. This concept could be extended to all long-term unemployed who do not match the requirements of the labor market. Both measures and jobs should be subject to individual freedom of choice.

True freedom of choice makes it more difficult to identify welfare fraud. A commonly accepted definition of reasonable work must be worked out to accomplish this purpose (Bonvin, 2007b). Although the impairments of capabilities discussed above reveal severe problems beyond the poverty trap, in cases where motivation is a problem, besides additional opportunities, constraints are also needed to promote a minimum commitment (Bonvin \& Farvaque, 2005). Overall the concept of valuable work will certainly result in greater difficulties for employers to find workers for jobs with bad working conditions.

\subsection{CA-compatible governance}

Just as the labor market instruments need modification and re-adjustment to cope with the CA, governance also requires a severe change. The current implementation of new public management was more adding targets and controlling in terms of management by objectives rather than replacing the former strict instructions for acting. The rigid system of orders, rules and central control is neither compatible with granting the required freedoms for customers, nor does it offer conditions for local agency. Fair compensation for more talented or skilled workers must be provided as well as opportunities for fair negotiation of working contracts for everyone. Nowadays policy forces the less-qualified unemployed to accept any contract conditions almost without any chance for negotiation (Farvaque, 2005) which leads to a decreasing level of wages, most of all for low-skilled workers (Arent \& Nagel, 2011).

The aspect of processual freedoms within the CA implies real participation of citizens in social policy. In the process of defining the term "valuable work" all stakeholders - employers, unemployed and workers - must be involved and contribute their interests as relevant information in a joint effort. The resulting specific regulations should leave sufficient freedom of individual choice but at the same time also accept adequate collective rationality (Bonvin \& Leßmann, 2011). For many long-term unemployed it is not possible to participate in this process due to both a lack of cognitive skills and the ability to adequately express their point of view. Alternatively organizations could take over the task of representing their interests against more privileged stakeholder groups. 
The same structure of cooperation of stakeholders would be suitable for the configuration of specific measures on the local level (Bonvin, 2007a). For provision of real participation a certain design of effective measures with full attention to needs and preferences of the customers on an independent local level is to be secured. The idea of a far-reaching agency on the local level would even correspond with a neo-liberal policy approach. Local actors would be provided with the necessary information for individual cases to aid in finding the best measures for each case (Bonvin \& Farvaque, 2005). Here the actors would perceive the requirement of changes within a dynamic environment sooner than is the case within the current centralistic system. A further requirement would be a counseling agency responsible for drafting an action plan for the customer, and not just for fulfilling technocratic requirements of statistics (Bartelheimer et al., 2008).

The cooperation of all actors on the local level should be supported and improved by network structures and designing appropriate measures (Bouché, 2008). Future demographic changes might motivate employers to join such networks, and diversity of employers can be the interface to private business (Voigt \& Wagner, 2007). For some long-term unemployed new forms of employment such as telework, home office jobs and forms of job-sharing might open up new opportunities. Extended continuous vocational training for low-skilled workers and workers aged above 50 reduces their unemployment risks of being disconnected from technological change. Here the need for a better synchronized joint effort of employers and public labor administration is obvious.

Figure 3: Suggested attributes of a long-term unemployment policy according to the capability approach

\begin{tabular}{|c|}
\hline Targets \\
\hline $\begin{array}{l}\text { Empowering } \\
\text { capabilities and } \\
\text { individual freedom }\end{array}$ \\
\hline Social participation \\
\hline Valuable work \\
\hline Sustainability \\
\hline
\end{tabular}

\begin{tabular}{|l|}
\hline \multicolumn{1}{|c|}{ Governance } \\
\hline $\begin{array}{l}\text { Integration of } \\
\text { different fields of } \\
\text { policy } \\
\text { Participation of } \\
\text { customers } \\
\text { Agency on the } \\
\text { level of local } \\
\text { actors }\end{array}$ \\
\hline
\end{tabular}

\begin{tabular}{|l|}
\hline \multicolumn{1}{|c|}{ Evaluation } \\
\hline Indicators oriented \\
to individual capa- \\
bilities: \\
-conversion factors \\
-freedoms \\
-functionings \\
Including qualita- \\
tive aspects \\
Sustainability \\
\hline
\end{tabular}

A CA-oriented policy should precisely define goals in order to avoid a capital mistake of the current labor market governance. At present the controlling system is focused on short-term indicators of political success and is drawing attention from roots of the problems (Robeyns, 2005). The shift must be made from resources-oriented statistics to capabilities-rating figures (Bonvin \& Farvaque, 2005). Traditional resource-oriented figures cannot represent the improvement of capabilities and instrumental freedoms (Bartelheimer et al., 2008). Besides the placement figures, information about tempo- 
rary work, limited or unlimited job contracts, additional information about the quality of jobs and sustainability parameters are needed for a CA-oriented evaluation of labor policy (Lugo, 2007).

A subset and data about achievable functioning and achieved functioning relevant for the evaluation of labor policy are to be defined and collected (Robeyns, 2005). Such results could be less convenient for immediate use in political public relations campaigns. The efficiency of simple activation measures which can be evaluated at a glance will be negated through the inclusion of the aspect of sustainability and might even indicate negative results. Mutually positive effects on capabilities and resources of customers have to be accounted for in evaluation. (Nicaise et al., 2005).

\section{Conclusions}

Considering the evidence of malfunction of the current labor administration in Germany, a new normative orientation based on the CA might provide the potential for reducing friction and enforcing sustainability. CA-oriented policy means turning from economic growth to extension of individual capabilities as the primary target. The normative base of the CA policy stands in conflict with the contemporary implicit axiom of neo-liberalism, so politics has to be defined anew. Not only social policy, but also economic policy has to follow the aim of re-enforcing individual capabilities and freedoms first and foremost. Different fields of policy need to be integrated and synchronized by the common normative basement of the CA.

In this spirit, intensification of case management in labor administration is the first step toward opening labor policy to this alternative approach. Placement for lowpaid jobs with poor working conditions might become more difficult without a policy forcing individuals into precarious work, but the current effect of promoting and subsidizing industries with low productivity cannot be seriously intended by social and economic policy. A new labor policy must also be able to cope with the growing problem of an underqualified workforce in a different way than paying UB II for workers in low-productive jobs as this cannot be seen as reasonable investment into human resources. CA-oriented labor policy invests in the labor force by promoting workers' occupational, social and cultural capital and thus their capabilities.

Such a policy should be a part of an integrated social policy with synchronized, all-round joint efforts for strengthening capabilities and personal conversion factors to increase the welfare of a state and should provide the required resources for individuals. It must also offer opportunities to choose between reasonable jobs and grant both the unemployed and professionals in the labor administration the chance for participation in shaping the policy and ample scope for trustful co-production in the consultation process. Politics must try to change the awareness, mentality and culture of society as a whole, to ensure fair conditions and welfare for all. The individual conditions for having opportunities for "valuable" work depend on structures, events and selfdependent decisions combined with decisions of all concerned and should be supported from pre-school age. 


\section{References}

Ames, A. (2008a). Arbeitssituation und Rollenverständnis der persönlichen Ansprechpartner/innen nach $\int 14$ SGB II. Düsseldorf.

Ames, A. (2008b). Hartz IV in Baden Württemberg - Die Erfabrungen der Betroffenen mit der Umsetzung und den Auswirkungen des SGB II. Düsseldorf.

Ames, A. (2009). Ursachen und Auswirkungen von Sanktionen nach \31 SGB II. Hans-Böckler-Stiftung, Düsseldorf.

Andersen, T. M., Holmström, B., Honkapohja, S., Korkman, S., Sönderström, H. T., \& Vartiainen, J. (2007). THE NORDIC MODEL - Embracing globalization and sharing risks. Helsinki.

Apel, H., \& Fertig, M. (2008). Operationalisierung von Beschäftigungsfäbigkeit - Ein methodischer Beitrag zur Entwicklung eines Messkonzepts. ISG Working Paper No. 3, Köln.

Arbeitskreis beschäftigungsorientiertes Fallmanagement im SGB II (2004). Fachkonzept beschäftigungsorientiertes Fallmanagement im SGB II. Nürnberg.

Arndt, C., \& Volkert, J. (2006). Amartya Sens Capability-Approach - Ein neues Konzept der deutschen Armuts- und Reichtumsberichterstattung. Vierteljabreshefte zur Wirtschaftsforschung, 75, 7-29.

Arndt, C., \& Volkert, J. (2007). A capability approach for official German poverty and wealth reports: Conceptual background and first empirical results. IAW Discussion Paper 27, Tübingen.

Arent, S., \& Nagl, W. (2011). Löhne und Arbeitslosengeld: Wie haben sich die Hartz-Reformen auf die Lohnentwicklung ausgewirkt? ifo Dresden berichtet, 18(3), 3-7.

Baccaro, L. (2010). Does the global financial crisis mark a turning point for labor? Socio Economic Review Discussion Forum 1, Labor and the global financial crisis, 341-348.

Bartelheimer, P., Moncel, N., Verd, J. M., Vero, J., \& Büttner, R. (2008). Towards analyzing individual working lives in a resources/capability perspective. In: Sen-sitising life course research? Exploring Amartya Sen's capability concept in comparative research on individual working lives. Dokumentation des CAPRIGHT Seminares, Göttingen.

Bartelheimer, P. (2010). Fünf Jahre Arbeitsmarktpolitik, nach dem SGB II. In: Agenda 2010 - Ziel erreicht? Hartz. IV in der Krise. Dokumentation der Bilanzierungskonferenz. Netzwerk SGB II, Hamburg.

Behn, R. D. (1994). Leadership counts - Lessons for public management from the Massachusetts Welfare, Training and Employment Program. Cambridge (MA): Harvard University Press.

Behrend, O., Sondermann, A., \& Ludwig-Mayerhofer, W. (2007). Auf der Suche nach der verlorenen Arbeit: Zur Krise der Arbeitsgesellschaft und ibrer (Nicht-Bewältigung in Praxis und Deutungsmustern von institutionellen Arbeitsvermittlern und Arbeitslosen. Siegen.

Behrend, O. (2008). Aktivieren als Form sozialer Kontrolle. Aus Politik und Zeitgeschicbte. 40-41, 16-21.

Berger, M. (2009). Psychische Erkrankungen: Klinik und Therapie. 3rd ed., München.

Berth, H., Black, F., Albani, C., Förster, P., Stöbel-Richter, Y., \& Brähler, E. (2008). Psychische Gesundheit und Arbeitslosigkeit. In Berufsverband Deutscher Psychologinnen und Psychologen (ed.), Psychische Gesundheit am Arbeitsplatz, in Deutschland (pp. 21-26). Berlin.

Bescherer, P., Dörre, K., Röbenack, S., \& Schierhorn, K. (2008). Eigensinnige „Kunden“. Auswirkungen strenger Zumutbarkeitsregeln auf Langzeitarbeitslose und perkär Beschäftigte. In Dörre, K., Behr, M., Bescherer, P., Robenack, S., Sweiwert, T., Kuhirt, K., \& Schierhorn, K.: Eigensinnige „Kunden“" Der Einfluss strenger Zumutbarkeit auf die Erwerbsorientierung Langzeitarbeitsloser und prekär Beschäftigter. SFB 580 Mitteilungen der Deutschen Forschungsgemeinschaft, Jena.

Bonvin, J.-M., \& Farvaque, N. (2005). Promoting capability for work. The role of local actors. Forthcoming in Deneulin, S., Nebel, M., \& Sagovsky, N. (eds.), Capability and justice. Towards structural transformation. Kluwer.

Bonvin, J.-M. (2007a). Entspricht die Europäische Beschäftigungsstrategie dem Ansatz der Verwirklichungschancen? Eine vorläufige Einschätzung. In Filipic, U. (ed.), Arbeitsmarktpolitik in Europa (pp. 11-26). Wien.

Bonvin, J.-M. (2007b). Internationale Organisationen und ihre Strategien der Beschäftigungsförderung: Die Beschäftigungs- und Arbeitsmarktkrise aus der Perspektive von OECD, EU und IAO. In Filipic, U. (ed.), Arbeitsmarktpolitik in Europa (pp. 52-67).Wien.

Bonvin, J.-M. (2009). Der Capability Ansatz und sein Beitrag für die Analyse gegenwärtiger Sozialpolitik. Soz: Passagen, 1, 8-22. 
Bonvin, J.-M., \& Leßmann, O. (2011). Job-satisfaction in the broader framework of the capability approach. Management Revue, 22(1), 84-99.

Bouché, P. (2008). Intermediäre Organisationen zu Umsetzung regionaler Arbeitsmarktpolitik in den deutschen Bundesländern unter dem Aspekt des Capability Approach. Discussion Paper WZB, Berlin.

Bourdieu, P. (1983). Ökonomisches Kapital, kulturelles Kapital, soziales Kapital. In: Kreckel, R. (ed.) Soziale Ungleichheiten. Soziale Welt, special issue 2, 183-195.

Bundesagentur für Arbeit (2010). Der Arbeitsmarkt in Deutschland: Zeitarbeit in Deutschland - Aktuelle Entwicklungen. Nürnberg.

Bundesagentur für Arbeit (2011). Arbeitsmarkt 2010. Amtliche Nachricbten der Bundesagentur für Arbeit, volume 8, special issue 2. Nürnberg.

BMAS - Bundesministerium für Arbeit und Soziales (2005). Lebenslagen in Deutscbland - Der 2. Armuts- und Reichtumsbericht der Bundesregierung. Berlin.

BMAS - Bundesministerium für Arbeit und Soziales (2008). Evaluation der Experimentierklausel nach $\int$ 6c SGB II - Vergleichende Evaluation des arbeitsmark.tpolitischen Erfolgs der Modelle der Aufgabenwabrnehmung "zugelassener kommunaler Träger" und "Arbeitsgemeinschaft" Untersuchungsfeld 2: Implementations- und Governanceanalyse. Berlin.

BMAS - Bundesministerium für Arbeit und Soziales (2011). Eckpunkte für ein Gesetz, zur „Leistungssteigerung der Arbeitsmark.tpolitischen Instrumente". Berlin.

Damelang, A., Haas, A. (2006). Arbeitsmarkteinstieg nach dualer Berufsausbildung - Migranten und Deutsche im Vergleich. IAB Forschungsbericht 17. Nürnberg.

Deakin, S. (2005). The „capability" concept and the evolution of European social policy. ESRC Centre for Business Research, University of Cambridge, Working Paper No. 303. Cambridge.

DGPPN - Deutsche Gesellschaft für Psychiatrie, Psychotherapie und Nervenheilkunde (2009). S2 Praxisleitlinien in Psychiatrie und Psychotherapie - Band1: Behandlungsleitlinie Persönlichkeitsstörungen. Berlin.

Dietz, M., Müller, G., \& Trappmann, M. (2009). Bedarfsgemeinschaften im SGB II - Warum Aufstocker trotz. Arbeit bedïrftig bleiben. IAB-Kurzberichte 2/2009, Nürnberg.

Drilling, M. (2004). Young urban poor: Abstiegsprozesse in den Zentren der Sozialstaaten. Wiesbaden.

Eichhorst, W., \& Zimmermann, K. F. (2007). Da waren's nur noch vier... Wie viele (und welche) Maßnahmen der aktiven Arbeitsmarktpolitik, brauchen wir noch? IZA Discussion Paper 2605, Bonn.

Farvaque, N. (2005). Unequal access to employment, unequal capabilities. French school-leavers' tranjectories in perspective. Paper to the $5^{\text {th }}$ International Capability Conference, UNESCO. Paris.

Forgas, J. P., \& Frey, D. (1999). Soziale Interaktion und Kommunikation. 4th ed., Weinheim.

Gebauer, R., Petschauer, H., \& Vobruba, G. (2003). Wer sitzt in der Armutsfalle - Selbstbehauptung zwischen Sozialbilfe und Arbeitsmarkt. 2nd ed., Berlin.

Goerne, A. (2010). The capability approach in social politic analysis. Working Papers on the Reconciliation of Work and Welfare in Europe. REC-WP 03/2010, online: http://www.socialpolicy.ed.ac.uk/recwowepudisc/working papers/rec-wp 0310

Granovetter, M. S. (1995). Getting a job: A study of contacts and careers. 2nd ed., Chicago.

Halapier, W., Holzinger, B., \& Puddu, S. (1996). Arbeitslos. Selbstbild, Selbstwert und Existenz in der Krise. In Hutterer-Krisch, R., Pfersmann, V., Farag, I. S. (eds.), Psychotherapie, Lebensqualität und Prophylaxe - Beiträge zur Gesundheitsvorsorge in Gesellschaftspolitik, Arbeitswelt und beim Individuum. Wien.

Hielscher, V., \& Ochs, P. (2009). Arbeitslos als Kunde? Beratungsgespräche in der Arbeitsvermittlung zwischen Druck und Dialog. Berlin.

IAB - Institut für Arbeitsmarkt- und Berufsforschung (2011). Jeder fünfte Geringqualifizierte ist arbeitslos. IAB-Aktuell Febuary 10, 2011, Nürnberg.

Kaps, P. (2006). Arbeitsmarktintegration oder Haushaltskonsolidierung? Interessen, Zielkonflikte und Ergebnisse kommunaler Beschäftigungspolitik. Wiesbaden.

Kommission zum Abbau der Arbeitslosigkeit und zur Umstrukturierung der Bundesanstalt für Arbeit (2002). Moderne Dienstleistungen am Arbeitsmarkt - Bericht der Kommission. Berlin.

Konle-Seidl, R. (2008). Changes in the governance of employment services in Germany since 2003. IAB Discussion Paper 10/2008, Nürnberg. 
Kraus, K. (2008). Does employability put the German „cocational order“ at risk? An analysis from the perspective of earning oriented pedagogy. In Gonon, P., Kraus, K., Oelkers, J., \& Stolz, S. (eds.), Work, education and employability. Bern.

Kuklys, W. (2005). Amataya Sen's capability approach: Theoretical insights and empirical applications. Berlin.

Lietzmann, T. (2009). Alleinerziehende in der Grundsicherung - Verzwickte Lage. In IAB-Forum 1/2009, 70-75.

Lipsky, M. (2005). Street-level bureaucracy: Dilemmas of the individual in public services. Publications of Russell Sage Foundation, New York.

Lugo, A.-M. (2007). Employment: A proposal for internationally comparable indicators. OPHI Working Paper No. 2, Oxford.

Nicaise, I., Rubbrecht, I., Matheus, N., \& D’Addio, A. (2005). Do active market policies invest in capabilities? The case of Flemish social enterprises. Tlm.net - working paper. Leuven.

Nicaise, I. (2007). Arbeitslosigkeit und Nichtbeschäftigung: Wege zu einem integrierten Konzept. Thematische Einleitung. Thematisches Seminar der Europäischen Beschäftigungsstrategie der Europäischen Kommission für Beschäftigung und Soziales, March 28, 2007.

Olejniczak, M. (2010). Aktive Leistungen nach dem SGB II als Dienstleistungsprozess. München.

Pfeifer, S., Hacket, A., Ritter, T., \& Schütt, P. (2008). Arbeitsvermögen und Arbeitslosigkeit - Empirische und theoretische Ergebnisse der SGB-II-Evaluation. München.

Pollak, R. (2006). Soziale Mobilität. In Statistisches Bundesamt (ed.), Datenreport 2006 - Zablen, und Fakten über die Bundesrepublik Deutschland, Teil 2 (pp. 597-606). Wiesbaden.

Robeyns, I. (2005). The capability approach: A theoretical survey. Journal of Human Development, 6(1), 93-114.

Salais, R. (2004). Social Europe and the capability approach. Source: http://cfs.unipv.it/ca2004/papers/salais.pdf, Paris

Schütz, H. (2008). Reform der Arbeitsvermittlung - Uniformierungsdruck in der Bundesagentur für Arbeit. Opladen.

Seibert, H., \& Kleinert, C. (2009). Duale Berufsausbildung - Ungelöste Probleme trotz Entspannung. IAB Kurzberichte 10/2009, Nürnberg.

Seifert, H. (2007). Die Hartz-Gesetze - Enttäusche Hoffnungen und neue Probleme. In Filipic, U. (ed.), Arbeitsmark.tpolitik. in Europa (pp. 27-40). Wien.

Sen, A. K. (1999). Development as freedom. Oxford.

Sesselmeier, W., \& Yollu-Tok, A. (2007). Pfadabweichungen und Akzeptanz von Arbeitsmarktreformen am Beispiel von Hartz IV. Landau.

Stadtland, C., Nedopil, N. (2008). Psychiatrische Begutachtung. In Dörfler, H., Eisenmerger, W., Lippert, H.-D., \& Wandl, U. (eds.), Medirinische Gutachten (pp. 487-520). Berlin.

Tisch, A. (2010). Kundenzufriedenheit im SGB II - Arbeitsvermittler im Urteil der Alg-II-Empfänger. IABKurzberichte 7/2010, Nürnberg.

Valtin, R. (2008). Soziale Ungleichheit in Deutschland - Zentrale Ergebnisse aus IGLU 2006 und PISA 2006. In Wernstedt, R., John-Ohnesorg, M. (eds.), Soziale Herkunft entscheidet über Bildungserfolg Konsquenzen aus IGLU 2006 und PIS A III. Dokumentation der Sitzung des Netzwerk Bildung vom 24. Januar 2008.

Vogel, B. (1999). Arbeitslosigkeit in Ostdeutschland. SOFI-Mitteilungen, 27, 15-23.

Voigt, B.-F., \& Wagner, D. (2007). Diversity-Management als Leitbild von Personalpolitik. Wiesbaden.

Volkert, J. (2005a). Amartya Sen's Capability-Ansatz als normative Ethik des Wirtschaftens. In Volkert, J. (ed.), Armut und Reichtum an Verwirklichungschancen - Amartya Sens Capability-Konzept als Grundlage der Armuts- und Reichtumsberichterstattung (pp. 23-45). Wiesbaden.

Volkert, J. (2005b) Das Capability-Konzept als Basis der Berichterstattung. In Volkert, J. (ed.), Armut und Reichtum an Verwirklichungschancen - Amartya Sens Capability-Konzept als Grundlage der Armuts- und Reichtumsberichterstattung (pp. 119-144). Wiesbaden.

Wacker, A. (2001) Was fehlt, wenn die Arbeit fehlt? Arbeitslosigkeit aus sozialpsychologischer Perspektive. In Becker, U., Segbers, F., Wiedemeyer, M. (eds.), Logik der Ökonomie - Krise der Arbeit. Impulse für eine solidarische Gestaltung der Arbeitswelt (pp. 51-64). Mainz.

Walker, M. (2010). The capability approach as a framework for reimagining education and justice. In Otto, H.-U., \& Ziegler, H. (eds.), Capabilities - Handlungsbefäbigung und Verwirklichungschancen in der Erziebungswissenschaft (pp. 116-130). 2nd ed. Wiesbaden.

Zierahn, U. (2009). Reform der schwedischen Arbeitsmarkt- und Tarifpolitik. HWWI Research Paper, Hamburg. 